Article

\title{
Heck Transformations of Biological Compounds Catalyzed by Phosphine-Free Palladium
}

\author{
Stanisława Tarnowicz-Ligus and Anna M. Trzeciak* \\ Faculty of Chemistry, University of Wrocław, 14 F. Joliot-Curie, 50-383 Wrocław, Poland; \\ stanislawa.tarnowicz@chem.uni.wroc.pl \\ * Correspondence: anna.trzeciak@chem.uni.wroc.pl; Tel.: +48-71-375-72-53; Fax: +48-71-328-23-48
}

Received: 30 June 2018; Accepted: 29 August 2018; Published: 1 September 2018

\begin{abstract}
The development and optimization of synthetic methods leading to functionalized biologically active compounds is described. Two alternative pathways based on Heck-type reactions, employing iodobenzene or phenylboronic acid, were elaborated for the arylation of eugenol and estragole. Cinnamyl alcohol was efficiently transformed to saturated arylated aldehydes in reaction with iodobenzene using the tandem arylation/isomerization sequential process. The arylation of cinnamyl alcohol with phenylboronic acid mainly gave unsaturated alcohol, while the yield of saturated aldehyde was much lower. Catalytic reactions were carried out using simple, phosphine-free palladium precursors and water as a cosolvent, following green chemistry rules as much as possible.
\end{abstract}

Keywords: palladium; arylation; Heck coupling; cinnamyl alcohol; linalool; eugenol; estragole

\section{Introduction}

The Heck reaction is one of the most convenient methods for $\mathrm{C}-\mathrm{C}$ bond formation applied in the preparation of many molecules developed as pharmaceuticals, agrochemicals, and functional materials [1-5]. In particular, it can be applied for allyl alcohol arylation catalyzed by $\operatorname{Pd}(0)$ nanoparticles [6]. On the other hand, Heck arylation suffers some drawbacks, such as the application of expensive and toxic aryl halides and the generation of harmful HX waste during the process $[7,8]$. The halide-free Heck-type reaction, employing arylboronic acid as an aryl source, can be considered an environmentally benign alternative [9-12]. The direct heteroarylation procedure presents another green pathway leading to arylated organic products [13,14].

Cinnamyl alcohol, eugenol, and estragole are natural compounds. The arylation of these compounds has so far not been intensively developed. Cinnamyl alcohol (3-phenyl-2-propen-1-ol) is used to obtain many cosmetics, perfumes, and detergents [15]. This alcohol has been arylated with iodobenzene to produce $\alpha, \beta$-unsatured alcohols by using TBAB (tetrabutylammonium bromide) and $\mathrm{NaHCO}_{3}$ as bases [16]. In analogous reactions performed in the presence of TBAA or without a base, exclusively carbonyl products have been formed [16]. The arylation of cinnamyl alcohol with different aryldiazonium salts under mild conditions in the presence of a $\mathrm{Pd}_{2}(\mathrm{dba})_{3}$ catalyst has been reported [17]. The regio- and stereoselective formation of (Z)-2,3-diarylallylic alcohols has been carried out using a palladium catalyst and the $\mathrm{n}-\mathrm{Bu}_{4} \mathrm{NOAc}$ base in toluene [18]. Arylboronic acid has been used for the arylation of cinnamic phenyl ether in the presence of $\mathrm{Pd}(\mathrm{OAc})_{2}$ and a hydrazone ligand [19].

Eugenol (1-allyl-3-methoxy-4-hydroxybenzene) is extracted from clove oil and marjoram, and it is present in spices such as basil, cinnamon, and nutmeg [20]. Eugenol can be employed in the synthesis of natural products, bioactive compounds, heterocycles, macrocycles, and polymers [21]. A methyl eugenol derivative has been arylated according to the Heck and oxidative Heck 
procedures to give products showing inhibitory effects on breast cancer cell metathesis [22]. Estragole ( $p$-allylanisole) occurs in basil oil, and it has antioxidative, antimicrobial [23], and anesthetic [24] properties. The arylation of estragole has been performed with bromobenzene and palladium polyether diphosphinite complex anchored in polyethylene glycol [25]. Linalool (3,7-dimethyl-1,6-octadien-3-ol) is a tertiary monoterpene alcohol which is a major component of the Coriandrum sativum essential oil. Moreover, it has very wide applications in the synthesis of fine fragrances, cosmetics, detergents, and other commercial derivatives [26-28]. Linalool leads to the corresponding $(E)$-1-arylalk-1-en-3-ol under the Heck conditions with a Pd-Tedicyp catalyst (Tedicyp = cis, cis, cis, -1,2,3,4-tetrakis(diphenylphosphinomethyl)cyclopentane) [29,30].

Considering a wide spectrum of biological properties of the above-mentioned compounds, interesting activities of their aryl derivatives can also be expected, as has already been shown for the eugenol derivative [22]. In our work, we focused on the application of phosphine-free palladium precursors $\left(\mathrm{Pd}(\mathrm{OAc})_{2}, \mathrm{PdCl}_{2} \mathrm{Cod}\right.$, or $\left.\mathrm{PdCl}_{2}\left(\mathrm{CH}_{3} \mathrm{CN}\right)_{2}\right)$ in two Heck-type arylation reactions employing iodobenzene or phenylboronic acid as an arylating agent. The application of phenylboronic acid avoids the formation of halide waste, in agreement with green chemistry rules. We also tested using water as a cosolvent in the reactions studied.

\section{Results and Discussion}

In order to get arylated derivatives of eugenol and estragole, two methods were tested and optimized. The first one was the Heck coupling with iodobenzene. In the second procedure, based on the Heck-type reaction, phenylboronic acid was employed as an arylating agent (Scheme 1). In this method, the base was eliminated from the system; however, the addition of a $\mathrm{Cu}$ (II) salt as an oxidant regenerating the catalytic amount of $\operatorname{Pd}(\mathrm{II})$ from $\operatorname{Pd}(0)$ was necessary [10-12,23]. The Heck-type reaction with the application of phenylboronic acid limits the formation of halide waste materials.
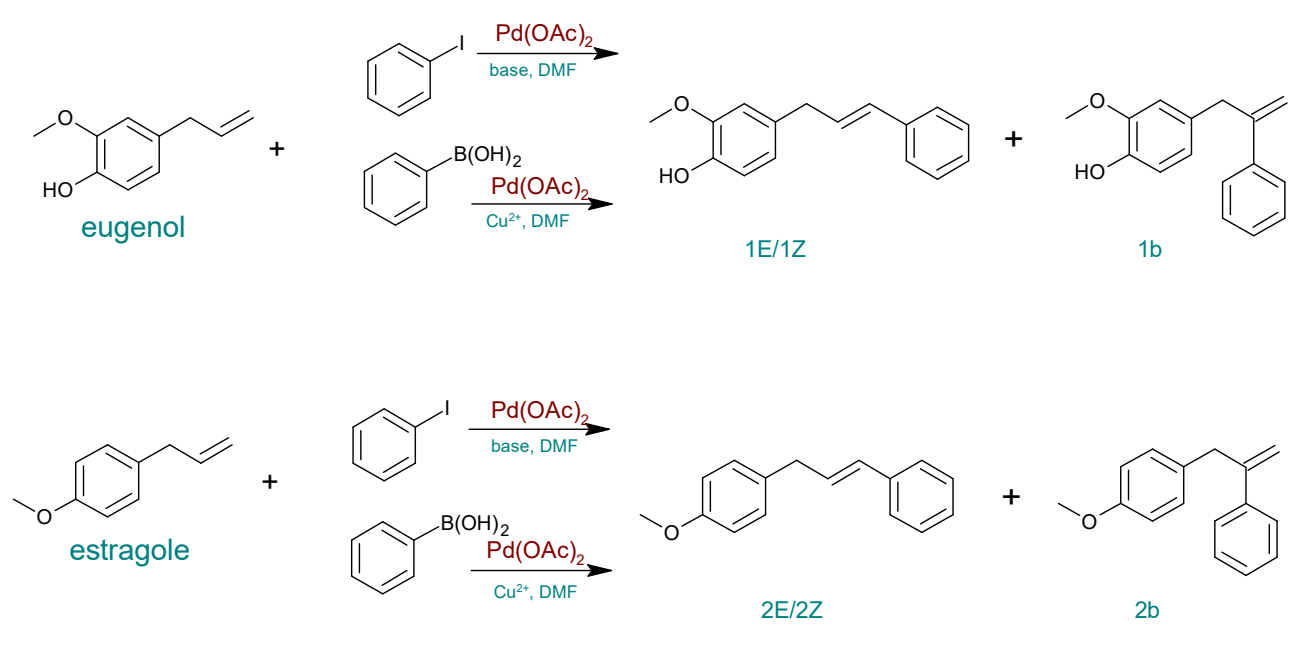

Scheme 1. Heck and Heck-type arylation of eugenol or estragole.

Table 1 presents the results of the Heck arylation of eugenole with iodobenzene. Three products, $1 \mathrm{E}, 1 \mathrm{Z}$, and $\mathbf{1 b}$, were identified, and the amount of $1 \mathrm{~b}$ was below $3 \%$ in all cases, while $1 \mathrm{E}$ was the main product. The first experiments, carried out for $3 \mathrm{~h}$ at $100{ }^{\circ} \mathrm{C}$ in DMF as a solvent, resulted in a $100 \%$ conversion of PhI with the formation of $81 \%$ of $1 \mathrm{E}$ and $16 \%$ of $\mathbf{1 Z}$. Very similar results were obtained after $1 \mathrm{~h}$ (95\% conversion). Further studies showed that the Heck arylation can be successfully performed in a DMF:water mixture (DMF:water $=4: 1$ or 2.5:2.5). The reaction rate slowed down at a higher content of water, and the yield of $1 \mathrm{E}$ was only $69 \%$ after $1 \mathrm{~h}$. However, after $2 \mathrm{~h}$, the conversion of $\mathrm{PhI}$ achieved $100 \%$ with a $79 \%$ yield of 1E. The conversion of $\mathrm{PhI}$ depended on the reaction temperature: it decreased at lower temperatures, $80{ }^{\circ} \mathrm{C}$ and $60{ }^{\circ} \mathrm{C}$, to $90 \%$ and $74 \%$, 
respectively, after $3 \mathrm{~h}$ (Table 1, entries 1, 11 and 12). On the other hand, product $\mathbf{1 b}$ was not formed at lower temperatures. Considering the effect of the catalyst type, $\mathrm{PdCl}_{2}\left(\mathrm{CH}_{3} \mathrm{CN}\right)_{2}$ turned out to be weaker than $\mathrm{Pd}(\mathrm{OAc})_{2}$, resulting in a 16\% lower conversion (Table 1, entry 2 and 9).

Table 1. Results of the Heck arylation of eugenol with iodobenzene.

\begin{tabular}{|c|c|c|c|c|c|c|c|c|c|}
\hline \multirow{2}{*}{ Entry } & \multirow{2}{*}{ Catalyst } & \multirow{2}{*}{ Base } & \multirow{2}{*}{$\mathrm{DMF}: \mathrm{H}_{2} \mathrm{O}$} & \multirow{2}{*}{$\mathrm{T}\left({ }^{\circ} \mathrm{C}\right)$} & \multirow{2}{*}{ Time (h) } & \multirow{2}{*}{ PhI Conversion (\%) } & \multicolumn{3}{|c|}{ Yield (\%) ${ }^{a}$} \\
\hline & & & & & & & $1 \mathrm{E}$ & $1 Z$ & $1 b$ \\
\hline 1 & \multirow{7}{*}{$\mathrm{Pd}(\mathrm{OAc})_{2}$} & \multirow{11}{*}{$\mathrm{K}_{2} \mathrm{CO}_{3}$} & DMF & 100 & 3 & 100 & 81 & 16 & 3 \\
\hline 2 & & & DMF & 100 & 1 & 95 & 78 & 15 & 2 \\
\hline 3 & & & $4: 1$ & 100 & 3 & 100 & 84 & 14 & 2 \\
\hline 4 & & & $4: 1$ & 100 & 2 & 100 & 85 & 15 & 0 \\
\hline 5 & & & $4: 1$ & 100 & 1 & 100 & 85 & 13 & 1 \\
\hline 6 & & & $2.5: 2.5$ & 100 & 2 & 100 & 79 & 21 & 0 \\
\hline 7 & & & $2.5: 2.5$ & 100 & 1 & 93 & 69 & 23 & 1 \\
\hline 9 & $\mathrm{PdCl}_{2}\left(\mathrm{CH}_{3} \mathrm{CN}\right)_{2}$ & & $\mathrm{DMF}$ & 100 & 1 & 79 & 74 & 5 & 0 \\
\hline 10 & \multirow{3}{*}{$\mathrm{Pd}(\mathrm{OAc})_{2}$} & & $4: 1$ & 100 & $40 \mathrm{~min}$ & 74 & 65 & 7 & 2 \\
\hline 11 & & & $4: 1$ & 80 & 3 & 90 & 80 & 10 & 0 \\
\hline 12 & & & $4: 1$ & 60 & 3 & 74 & 68 & 6 & 0 \\
\hline
\end{tabular}

Reaction conditions (method A): PhI (1 mmol), eugenol (1 mmol), $\mathrm{K}_{2} \mathrm{CO}_{3}(2 \mathrm{mmol}),[\mathrm{Pd}]\left(1 \times 10^{-5} \mathrm{~mol}\right), \mathrm{DMF}$ or mixture of DMF with $\mathrm{H}_{2} \mathrm{O}\left(5 \mathrm{~cm}^{3}\right)$. ${ }^{\text {a }}$ GC yield.

Next, the Heck arylation of estragole with iodobenzene was studied (Table 2). After $3 \mathrm{~h}$ of a reaction carried out at $100{ }^{\circ} \mathrm{C}$, the conversion of iodobenzene reached $96 \%$, and the yields of the main products, 2E and 2Z, were comparable, $47 \%$ and $42 \%$, respectively. The presence of water resulted in a decrease in PhI conversion to $61 \%$ at the DMF: $\mathrm{H}_{2} \mathrm{O}$ ratio equal 4:1. In all experiments, the amount of product $\mathbf{2} \mathbf{b}$ was as low as $3-7 \%$.

Table 2. Results of the Heck arylation of estragole with iodobenzene.

\begin{tabular}{|c|c|c|c|c|c|c|c|c|c|}
\hline \multirow{2}{*}{ Entry } & \multirow{2}{*}{ Catalyst } & \multirow{2}{*}{ Base } & \multirow{2}{*}{ DMF: $\mathrm{H}_{2} \mathrm{O}$} & \multirow{2}{*}{$\mathrm{T}\left({ }^{\circ} \mathrm{C}\right)$} & \multirow{2}{*}{ Time (h) } & \multirow{2}{*}{ PhI Conversion (\%) } & \multicolumn{3}{|c|}{ Yield (\%) ${ }^{a}$} \\
\hline & & & & & & & $2 \mathrm{E}$ & $2 Z$ & $2 b$ \\
\hline 1 & \multirow{7}{*}{$\mathrm{Pd}(\mathrm{OAc})_{2}$} & \multirow{7}{*}{$\mathrm{K}_{2} \mathrm{CO}_{3}$} & DMF & 80 & 3 & 71 & 36 & 30 & 5 \\
\hline 2 & & & DMF & 100 & 3 & 96 & 47 & 42 & 7 \\
\hline 4 & & & DMF & 100 & 1 & 77 & 40 & 31 & 6 \\
\hline 5 & & & $2.5: 2.5$ & 100 & 1 & 41 & 24 & 14 & 3 \\
\hline 3 & & & $4: 1$ & 100 & 3 & 61 & 35 & 22 & 4 \\
\hline 6 & & & $4: 1$ & 100 & 1 & 15 & 11 & 4 & 0 \\
\hline 7 & & & $4: 1$ & 80 & 3 & 37 & 28 & 9 & 0 \\
\hline
\end{tabular}

Reaction conditions (method A): PhI (1 mmol), estragole (1 mmol), $\mathrm{K}_{2} \mathrm{CO}_{3}(2 \mathrm{mmol})$, [Pd] $\left(1 \times 10^{-5} \mathrm{~mol}\right)$, DMF or a mixture of DMF and $\mathrm{H}_{2} \mathrm{O}\left(5 \mathrm{~cm}^{3}\right)$. ${ }^{a} \mathrm{GC}$ yield.

In the alternative Heck-type procedure with phenylboronic acid used instead of iodobenzene, the base was eliminated and copper salts, $\mathrm{Cu}(\mathrm{OAc})_{2}$ or $\mathrm{Cu}(\mathrm{OAc})_{2} \cdot \mathrm{H}_{2} \mathrm{O}$, were added (Scheme 1 , Table 3). The best result, $92 \%$ conversion of eugenol, was achieved after $4 \mathrm{~h}$ at $100{ }^{\circ} \mathrm{C}$ (Table 3, entry 8). Two products, 1E and 1Z, were formed in comparable amounts, 46 and 39\%, respectively. In almost all experiments performed according to this procedure, the yields of $\mathbf{1 E}$ and $\mathbf{1 Z}$ were similar. This is different from the Heck method with iodobenzene, which favored product 1E over 1Z. Only in one case, in a shorter reaction of $3 \mathrm{~h}$, was the excess of $\mathbf{1 E}$ over $\mathbf{1 Z}$ significant (26\%) (Table 3, entry 7 ). However, the prolongation of this reaction to $4 \mathrm{~h}$ resulted in an increase in the yield of 1E. The Heck-type procedure with phenylboronic acid was successful only when copper salts were employed as palladium oxidants. In contrast, arylation products were not formed in reactions performed in air (Table 3). 
Table 3. Results of the Heck-type arylation of eugenol with phenylboronic acid.

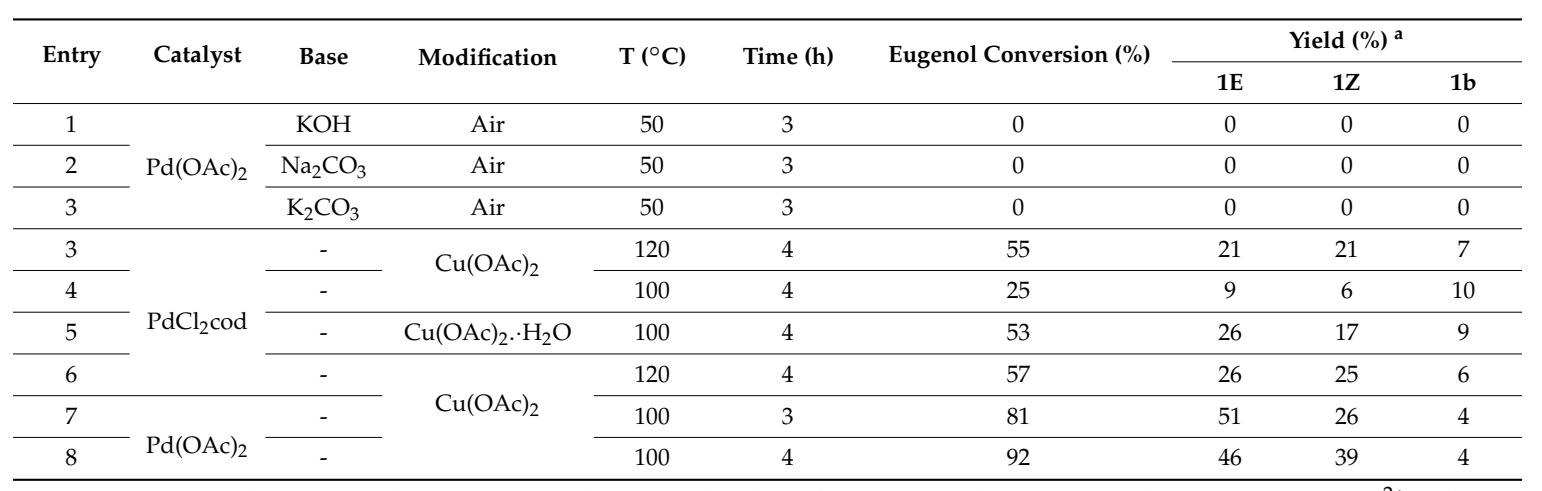

Reaction conditions (method B): eugenol (1 mmol), phenylboronic acid $(1.5 \mathrm{mmol})$, base $(2 \mathrm{mmol}), \mathrm{Cu}^{2+}$ salt $(2 \mathrm{mmol}),[\mathrm{Pd}]\left(1 \times 10^{-5} \mathrm{~mol}\right), \operatorname{DMF}\left(5 \mathrm{~cm}^{3}\right) .{ }^{\text {a }} \mathrm{GC}$ yield.

Eugenol reacted faster according to the Heck procedure, and the conversion of $\mathrm{PhI}$ was $100 \%$ already after $1 \mathrm{~h}$ (Table 1, entry 5). In the Heck-type reaction, a conversion of $92 \%$ was achieved in $4 \mathrm{~h}$ (Table 3, entry 8).

Estragole was efficiently arylated with phenylboronic acid under the same conditions (Table 4). In this case, the positive effect of copper salts on the reaction course was also noted, while products were not formed in air atmosphere without copper. The best result, $92 \%$ conversion of estragole, was obtained after $4 \mathrm{~h}$ at $100{ }^{\circ} \mathrm{C}$. Both products, $2 \mathrm{E}$ and $2 \mathrm{Z}$, were formed in comparable amounts, 47 and $41 \%$, respectively. In general, this method gave similar results to that with iodobenzene.

Table 4. Results of the Heck-type reaction of estragole with phenylboronic acid.

\begin{tabular}{|c|c|c|c|c|c|c|c|c|c|}
\hline \multirow{2}{*}{ Entry } & \multirow{2}{*}{ Catalyst } & \multirow{2}{*}{ Base } & \multirow{2}{*}{ Modification } & \multirow{2}{*}{$\mathrm{T}\left({ }^{\circ} \mathrm{C}\right)$} & \multirow{2}{*}{ Time (h) } & \multirow{2}{*}{ Estragole Conversion (\%) } & \multicolumn{3}{|c|}{ Yield $(\%)^{a}$} \\
\hline & & & & & & & $2 \mathrm{E}$ & $2 Z$ & $2 b$ \\
\hline 1 & \multirow{2}{*}{$\mathrm{Pd}(\mathrm{OAc})_{2}$} & $\mathrm{KOH}$ & Air & 50 & 3 & 0 & 0 & 0 & 0 \\
\hline 2 & & $\mathrm{Na}_{2} \mathrm{CO}_{3}$ & Air & 50 & 3 & 0 & 0 & 0 & 0 \\
\hline 3 & \multirow{3}{*}{$\mathrm{PdCl}_{2} \mathrm{cod}$} & - & \multirow{2}{*}{$\mathrm{Cu}(\mathrm{OAc})_{2}$} & 120 & 4 & 64 & 34 & 28 & 2 \\
\hline 4 & & - & & 100 & 4 & 34 & 22 & 12 & 0 \\
\hline 5 & & - & $\mathrm{Cu}(\mathrm{OAc})_{2} \cdot \mathrm{H}_{2} \mathrm{O}$ & 100 & 4 & 59 & 32 & 24 & 3 \\
\hline 6 & \multirow{3}{*}{$\mathrm{Pd}(\mathrm{OAc})_{2}$} & - & \multirow{3}{*}{$\mathrm{Cu}(\mathrm{OAc})_{2}$} & 100 & 2.5 & 89 & 46 & 39 & 4 \\
\hline 7 & & - & & 100 & 3 & 90 & 49 & 37 & 4 \\
\hline 8 & & - & & 100 & 4 & 92 & 47 & 41 & 4 \\
\hline
\end{tabular}

The arylation of cinnamyl alcohol with iodobenzene produced a mixture of products with saturated aldehydes 3 and 4 being the main ones (Scheme 2). The formation of these products can be explained by a tandem process involving the isomerization of the Heck-reaction product, namely di-arylated allylic alcohol, produced in the first step [16]. The small amounts of unsaturated aldehydes 5 and $\mathbf{6}$ were probably formed by the $\operatorname{Pd}(\mathrm{II})$-catalyzed dehydrogenation of 3 and 4 [31].

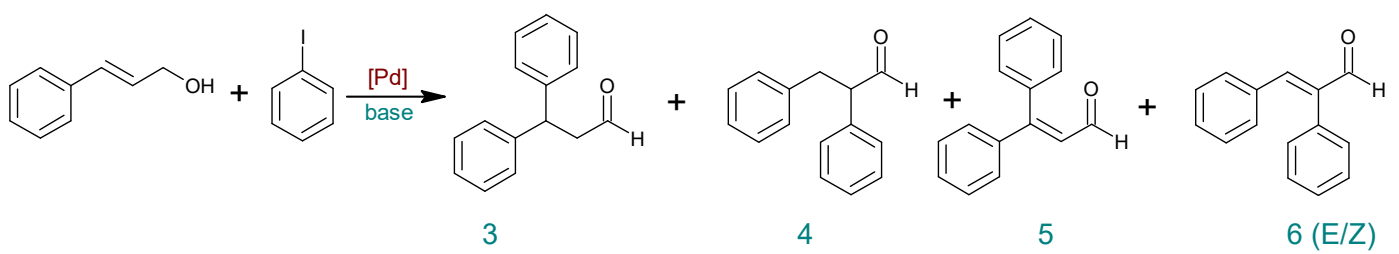

Scheme 2. Heck coupling of cinnamyl alcohol. 
The data collected in Table 5 indicate the positive effect of water on the reaction course. For example, the yield of product 3 was $13 \%$, and that of product 4 was $29 \%$, after a 6 h reaction in DMF. When the same reaction was carried out in DMF: $\mathrm{H}_{2} \mathrm{O}(1: 1)$, the yield of products 3 and 4 increased to 34 and 57\%, respectively. Moreover, in the presence of water, the formation of a biphenyl side product was completely suppressed (Table 5, entry 3). Unfortunately, attempts to increase the amount of water to the DMF: $\mathrm{H}_{2} \mathrm{O}$ ratio of 1:4 resulted in a biphenyl yield increase to $19 \%$, although the conversion of iodobenzene was quite high (93\%) (Table 5, entry 4). Good results were also obtained in the presence of a TBAB additive (Table 5, entry 2). The formation of side products 5 and $\mathbf{6}$ was noted in few cases.

Table 5. Results of the Heck reaction of cinnamyl alcohol with iodobenzene.

\begin{tabular}{|c|c|c|c|c|c|c|c|c|c|c|}
\hline \multirow{2}{*}{ Entry } & \multirow{2}{*}{ Catalyst } & \multirow{2}{*}{ Base } & \multirow{2}{*}{ Modification } & \multirow{2}{*}{ Time (h) } & \multirow{2}{*}{ PhI Conversion (\%) } & \multicolumn{5}{|c|}{ Yield (\%) ${ }^{b}$} \\
\hline & & & & & & Bif. & 3 & 4 & 5 & 6 \\
\hline 1 & $\mathrm{PdCl}_{2} \operatorname{cod}$ & \multirow{4}{*}{$\mathrm{NaOAc}$} & - & 6 & 68 & 15 & 13 & 29 & 7 & 2 \\
\hline 2 & $\mathrm{PdCl}_{2} \mathrm{cod}$ & & $\mathrm{TBAB}^{\mathrm{a}}$ & 6 & 91 & 5 & 28 & 52 & 3 & 3 \\
\hline 3 & $\mathrm{PdCl}_{2} \mathrm{cod}$ & & $\begin{array}{c}\text { DMF: } \mathrm{H}_{2} \mathrm{O} \\
(1: 1)\end{array}$ & 6 & 93 & - & 34 & 57 & - & - \\
\hline 4 & $\mathrm{PdCl}_{2} \mathrm{cod}$ & & $\begin{array}{c}\text { DMF: } \mathrm{H}_{2} \mathrm{O} \\
(4: 1)\end{array}$ & 6 & 93 & 19 & 14 & 53 & - & - \\
\hline 5 & $\mathrm{PdCl}_{2} \mathrm{cod}$ & \multirow{4}{*}{$\mathrm{K}_{2} \mathrm{HPO}_{4}$} & - & 6 & 30 & - & 11 & 19 & - & - \\
\hline 6 & \multirow{2}{*}{$\mathrm{PdCl}_{2} \mathrm{cod}$} & & \multirow{2}{*}{$\begin{array}{c}\text { DMF: } \mathrm{H}_{2} \mathrm{O} \\
(1: 1)\end{array}$} & 6 & 56 & 10 & 18 & 28 & - & - \\
\hline 7 & & & & 24 & 96 & 2 & 8 & 72 & - & 11 \\
\hline 8 & $\mathrm{PdCl}_{2} \operatorname{cod}$ & & $\begin{array}{c}\text { DMF: } \mathrm{H}_{2} \mathrm{O} \\
(1: 4)\end{array}$ & 6 & 68 & 10 & 13 & 40 & - & - \\
\hline 9 & \multirow{2}{*}{$\mathrm{PdCl}_{2} \mathrm{cod}$} & \multirow{2}{*}{$\mathrm{Et}_{3} \mathrm{~N}$} & - & 6 & 68 & 24 & 22 & 18 & - & - \\
\hline 10 & & & $\begin{array}{c}\text { DMF: } \mathrm{H}_{2} \mathrm{O} \\
(1: 1)\end{array}$ & 6 & 67 & 5 & 26 & 36 & - & - \\
\hline
\end{tabular}

Reaction conditions (method C): PhI (1 mmol), cinnamyl alcohol (1 mmol), base $(2 \mathrm{mmol}),[\mathrm{Pd}]\left(1 \times 10^{-5} \mathrm{~mol}\right)$, DMF or DMF mixed with $\mathrm{H}_{2} \mathrm{O}\left(5 \mathrm{~cm}^{3}\right), 100{ }^{\circ} \mathrm{C}^{\text {a }} 1 \mathrm{~g}$ of TBAB was added. ${ }^{\mathrm{b}} \mathrm{GC}$ yield.

Next, the reaction of cinnamyl alcohol with phenylboronic acid was studied (Scheme 3). In these conditions, $\mathrm{PdCl}_{2}$ cod was not active, and $\mathrm{Pd}(\mathrm{OAc})_{2}$ and $\mathrm{Pd}_{2}(\mathrm{dba})_{3}$ were used as catalysts. Interestingly, the unsaturated alcohol 7, which was not obtained in reaction with iodobenzene, was formed as the main product in this case (Table 6). Arylation with phenylboronic acid was rather fast, and, already after $1 \mathrm{~h}$ at $50{ }^{\circ} \mathrm{C}, 100 \%$ of the alcohol was converted to afford $74 \%$ of 7 together with $20 \%$ and $6 \%$ of products 3 and 4, respectively. At a higher temperature, $100{ }^{\circ} \mathrm{C}$, the yield of the side product, biphenyl, increased.

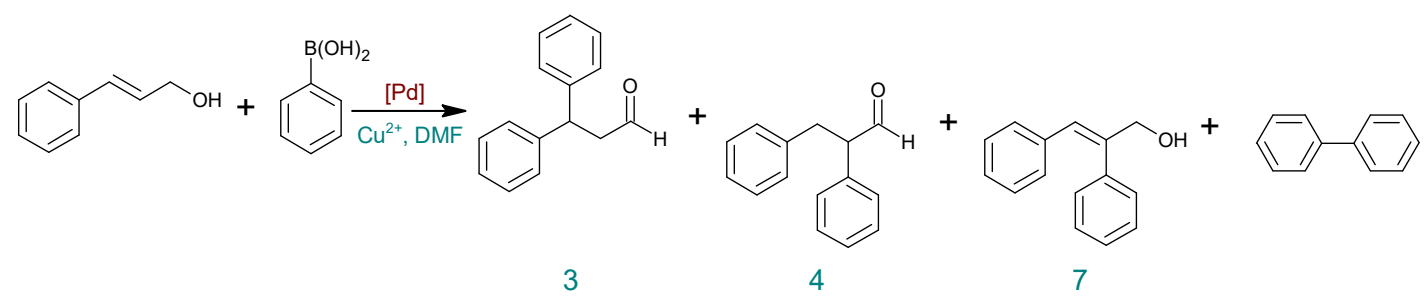

Scheme 3. The Heck-type arylation of cinnamyl alcohol with phenylboronic acid. 
Table 6. Results of the Heck-type arylation of cinnamyl alcohol with phenylboronic acid.

\begin{tabular}{|c|c|c|c|c|c|c|c|c|}
\hline \multirow{2}{*}{ Entry } & \multirow{2}{*}{ Catalyst } & \multirow{2}{*}{ Salt $\mathrm{Cu}^{2+}$} & \multirow{2}{*}{$\mathrm{T}\left({ }^{\circ} \mathrm{C}\right)$} & \multirow{2}{*}{ Time (h) } & \multirow{2}{*}{$\begin{array}{c}\text { Cinnamyl Alcohol } \\
\text { Conversion }(\%)\end{array}$} & \multicolumn{3}{|c|}{ Yield (\%) } \\
\hline & & & & & & 3 & 4 & 7 \\
\hline 1 & \multirow{4}{*}{$\mathrm{Pd}(\mathrm{OAc})_{2}$} & Air & 100 & 4 & 0 & 0 & 0 & 0 \\
\hline 2 & & \multirow{7}{*}{$\mathrm{Cu}(\mathrm{OAc})_{2}$} & 100 & 6 & 100 & 37 & 14 & 49 \\
\hline 3 & & & 100 & 4 & 100 & 40 & 16 & 44 \\
\hline 4 & & & 50 & 1 & 90 & 18 & 6 & 63 \\
\hline 5 & \multirow{4}{*}{$\mathrm{Pd}_{2}(\mathrm{dba})_{3}$} & & 50 & 4 & 100 & 19 & 6 & 75 \\
\hline 6 & & & 50 & 1 & 100 & 20 & 6 & 74 \\
\hline $7^{a}$ & & & 50 & 1 & 63 & 13 & 5 & 45 \\
\hline 8 & & & 50 & 0.5 & 90 & 25 & 8 & 56 \\
\hline
\end{tabular}

Reaction conditions (method B): cinnamyl alcohol (1 mmol), phenylboronic acid (1.5 mmol), $\mathrm{Cu}^{2+}$ salt $(2 \mathrm{mmol})$, [Pd] $\left(1 \times 10^{-5} \mathrm{~mol}\right), \operatorname{DMF}\left(5 \mathrm{~cm}^{3}\right),{ }^{\mathrm{a}}[\mathrm{Pd}]\left(0.5 \times 10^{-5} \mathrm{~mol}\right) .{ }^{\mathrm{b}} \mathrm{GC}$ yield.

Considering the activity of the catalysts used, it is worth noting that the activity of the $\operatorname{Pd}(0)$ complex was similar to that of the $\mathrm{Pd}(\mathrm{II})$ compound. The conversion of the substrate was high for both catalysts; however, $\mathrm{Pd}_{2}(\mathrm{dba})_{3}$ preferably produced product 7 , due to slow isomerization to 4 . According to the well-accepted mechanism of the oxidative Heck coupling, $\mathrm{Pd}(\mathrm{II})$ is assumed to be catalytically active $[10,11,23]$. However, we have no evidence of the oxidation of $\operatorname{Pd}_{2}\left(\mathrm{dba}_{3}\right.$ in our system.

The last substrate studied was linalool (Scheme 4). It reacted smoothly with iodobenzene forming products 8 and 9 .

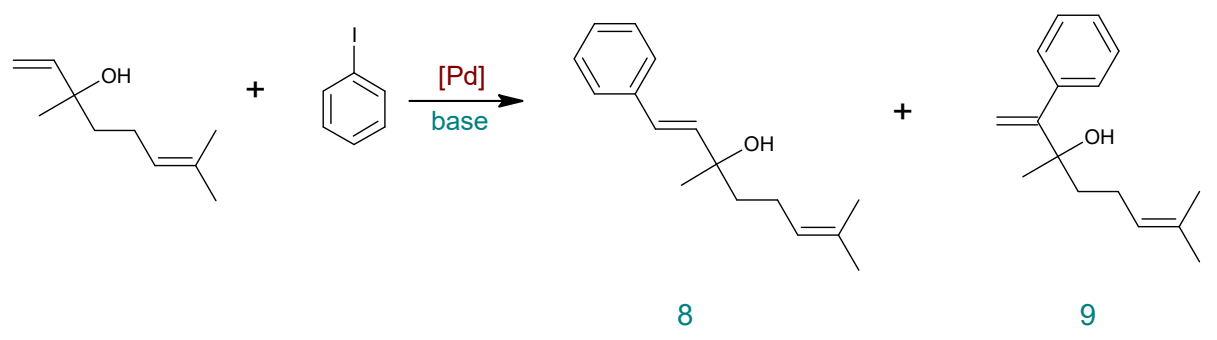

Scheme 4. Heck coupling of linalool.

As shown in Table 6, the conversion of iodobenzene after $3 \mathrm{~h}$ was $42-47 \%$, while it increased significantly, to $61-95 \%$, after a change of the solvent from DMF alone to a DMF/water mixture (Table 7 , entries 2 and 4). Considering the base, $\mathrm{NaOAc}$ was found the most efficient, enabling the formation of $66 \%$ of product 8 and $29 \%$ of product 9 . Unfortunately, linalool did not react with phenylboronic acid under Heck-type conditions with $\mathrm{Pd}(\mathrm{OAc})_{2}$ as a catalyst. 
Table 7. Results of the Heck arylation of linalool with iodobenzene.

\begin{tabular}{|c|c|c|c|c|c|c|c|}
\hline \multirow{2}{*}{ Entry } & \multirow{2}{*}{ Catalyst } & \multirow{2}{*}{ Base } & \multirow{2}{*}{ Modification } & \multirow{2}{*}{ Time (h) } & \multirow{2}{*}{ PhI Conversion (\%) } & \multicolumn{2}{|c|}{${\text { Yield }(\%)^{a}}^{a}$} \\
\hline & & & & & & 8 & 9 \\
\hline 1 & \multirow{6}{*}{$\mathrm{PdCl}_{2} \mathrm{cod}$} & \multirow[b]{2}{*}{$\mathrm{NaOAc}$} & - & 3 & 47 & 33 & 14 \\
\hline 2 & & & $\begin{array}{c}\text { DMF: } \mathrm{H}_{2} \mathrm{O} \\
(4: 1)\end{array}$ & 3 & 95 & 66 & 29 \\
\hline 3 & & \multirow[b]{2}{*}{$\mathrm{K}_{2} \mathrm{HPO}_{4}$} & - & 3 & 42 & 21 & 21 \\
\hline 4 & & & $\begin{array}{c}\text { DMF: } \mathrm{H}_{2} \mathrm{O} \\
(4: 1)\end{array}$ & 3 & 65 & 48 & 17 \\
\hline 5 & & \multirow[b]{2}{*}{$\mathrm{Et}_{3} \mathrm{~N}$} & - & 3 & 42 & 29 & 12 \\
\hline 6 & & & $\begin{array}{c}\text { DMF: } \mathrm{H}_{2} \mathrm{O} \\
(4: 1)\end{array}$ & 3 & 61 & 45 & 12 \\
\hline
\end{tabular}

Reaction conditions (method C): PhI (1 mmol), linalool (1 mmol), base (2 mmol), [Pd] $\left(1 \times 10^{-5} \mathrm{~mol}\right), 100{ }^{\circ} \mathrm{C}, \mathrm{DMF}$ or mixed DMF with $\mathrm{H}_{2} \mathrm{O}\left(5 \mathrm{~cm}^{3}\right)$. ${ }^{\text {a }} \mathrm{GC}$ yield.

\section{Materials and Methods}

\subsection{Reactants}

Iodobenzene, eugenol, estragole, cinnamyl alcohol, linalool, and phenylboronic acid (Sigma Aldrich, Poznań, Poland) were used without purification or drying.

\subsection{General Procedures}

\subsubsection{Heck Reaction (Method A)}

The reaction was carried out in a $50 \mathrm{~cm}^{3}$ Schlenk tube. The solid substrates, the base $(2 \mathrm{mmol})$, and the Pd catalyst $\left(1 \times 10^{-5} \mathrm{~mol}\right)$ were weighed and placed in the Schlenk tube under an $\mathrm{N}_{2}$ atmosphere. Next, olefin (1 mmol), iodobenzene $(1 \mathrm{mmol})$, and $5 \mathrm{~cm}^{3}$ of the solvent (DMF alone or DMF mixed with water) were added with a pipette. The Schlenk tube was closed with a rubber plug, and the reaction mixture was stirred at $60-100{ }^{\circ} \mathrm{C}$ in oil bath. After the given reaction time, the Schlenk tube was cooled down, and the organic products were separated by extraction with diethyl ether (three times with 5,4 , and $2 \mathrm{~cm}^{3}$ ). For better phase separation, $5 \mathrm{~cm}^{3}$ of water was added, and the products were GC-MS analyzed (Hewlett Packard 8454A (Palo Alto, CA, USA)) with mesitylene $\left(0.1 \mathrm{~cm}^{3}\right)$ as the internal standard. The GC yield given in the Table means the substrate conversion to a given product. Physicochemical data of reaction products can be found in Supplementary Materials.

\subsubsection{Heck-Type Reaction (Method B)}

The reaction was carried out in a $50 \mathrm{~cm}^{3}$ Schlenk tube. The solid substrates, copper (II) acetate ( $2 \mathrm{mmol})$, phenylboronic acid $(1.5 \mathrm{mmol})$, and the Pd catalyst $\left(1 \times 10^{-5} \mathrm{~mol}\right)$ were weighed and placed in the Schlenk tube under an $\mathrm{N}_{2}$ atmosphere. Next, olefin $(1 \mathrm{mmol})$ and $5 \mathrm{~cm}^{3}$ of the solvent (DMF alone or DMF mixed with water) were added with a pipette. The Schlenk tube was closed with a rubber plug, and the reaction mixture was stirred at $50-120^{\circ} \mathrm{C}$ in oil bath. After the given reaction time, the Schlenk tube was cooled down, and the organic products were separated by extraction with diethyl ether (three times with 5,4 , and $2 \mathrm{~cm}^{3}$ ). For better phase separation, $5 \mathrm{~cm}^{3}$ of water was added, and the products were GC-MS analyzed (Hewlett Packard $8454 \mathrm{~A}$ ) with mesitylene $\left(0.1 \mathrm{~cm}^{3}\right)$ as the internal standard. The GC yield given in the Table means the substrate conversion to a given product. Physicochemical data of reaction products can be found in Supplementary Materials. 


\subsubsection{Heck-Type Reaction (Method C)}

The reaction was carried out in a $50 \mathrm{~cm}^{3}$ Schlenk tube. The solid substrates, the base $(2 \mathrm{mmol})$, and the $\mathrm{PdCl}_{2} \operatorname{cod}\left(1 \times 10^{-5} \mathrm{~mol}\right)$ were weighed and placed in the Schlenk tube under an $\mathrm{N}_{2}$ atmosphere. Next, iodobenzene $(1 \mathrm{mmol})$, cinnamyl alcohol or linalool $(1 \mathrm{mmol})$, and $5 \mathrm{~cm}^{3}$ of the solvent (DMF alone or DMF mixed with water) were added with a pipette. The Schlenk tube was closed with a rubber plug, and the reaction mixture was stirred at $50-100{ }^{\circ} \mathrm{C}$ in oil bath. After the given reaction time, the Schlenk tube was cooled down, and the organic products were separated by extraction with diethyl ether (three times with 7, 3, and $2 \mathrm{~cm}^{3}$ ). For better phase separation, $5 \mathrm{~cm}^{3}$ of water was added, and the products were GC-MS analyzed (Hewlett Packard 8454A) with mesitylene $\left(0.1 \mathrm{~cm}^{3}\right)$ as the internal standard. The GC yield given in the Table means the substrate conversion to a given product. Physicochemical data of reaction products can be found in Supplementary Materials.

\section{Conclusions}

We presented two efficient methods based on palladium-catalyzed Heck procedures, leading to arylated products of biological importance. In particular, it was discovered that water serving as a co-solvent significantly enhanced product yield.

The Heck-type reaction employing phenylboronic acid and $\mathrm{Cu}^{2+}$ salts was tested for the first time in the arylation of eugenol and estragole, and the obtained results were very promising. In this procedure, the iodobenzene substrate was substituted by phenylboronic acid, which improved the economic and environmental aspects. The same method applied to cinnamyl alcohol enabled the preparation of arylated unsaturated alcohol in $1 \mathrm{~h}$ at $50^{\circ} \mathrm{C}$.

In the Heck coupling of cinnamyl alcohol with iodobenzene, diarylated saturated aldehydes were obtained. Also in this case, the addition of water resulted in an increase in iodobenzene conversion by over $20 \%$, and $57 \%$ of 2,3-diphenylpropanal was formed. Similarly, the arylation of linalool in a DMF: $\mathrm{H}_{2} \mathrm{O}$ mixture gave better results (66\% of product 8 and $29 \%$ of product 9 ) than a reaction carried out in the absence of water (33\% of product 8 and $14 \%$ of product 9 ).

Supplementary Materials: Supplementary materials are available on line.

Author Contributions: S.T.-L. performed experiments, analyzed the obtained results and prepared the manuscript. A.M.T. defined the work plan and the research methodology, elaborated the final version of the manuscript.

Funding: Financial support of National Science Centre (NCN, Poland) with grant 2014/15/B/ST5/02101 is gratefully acknowledged.

Conflicts of Interest: The authors declare no conflict of interest.

\section{References}

1. Heck, R.F. Palladium-catalyzed reactions of organic halides with olefins. Acc. Chem. Res. 1979, 12, 146-151. [CrossRef]

2. Beletskaya, I.P.; Cheprakov, A.V. The Heck Reaction as a Sharpening Stone of Palladium Catalysis. Chem. Rev. 2000, 100, 3009-3066. [CrossRef] [PubMed]

3. Dounay, A.B.; Overman, L.E. The Asymmetric Intramolecular Heck Reaction in Natural Product Total Synthesis. Chem. Rev. 2003, 103, 2945-2964. [CrossRef] [PubMed]

4. Nicolaou, K.C.; Bulger, P.G.; Sarlah, D. Palladium-Catalyzed Cross-Coupling Reactions in Total Synthesis. Angew. Chem. Int. Ed. 2005, 44, 4442-4489. [CrossRef] [PubMed]

5. Torborg, C.; Beller, M. Recent Applications of Palladium-Catalyzed Coupling Reactions in the Pharmaceutical, Agrochemical, and Fine Chemical Industries. Adv. Synth. Catal. 2009, 351, 3027-3043. [CrossRef]

6. Tarnowicz, S.; Alsalahi, W.; Mieczynska, E.; Trzeciak, A.M. Heck arylation of allyl alcohol catalyzed by Pd(0) nanoparticles. Tetrahedron 2017, 73, 5605-5612. [CrossRef]

7. Heravi, M.M.; Fazeli, A. Recent Advances in the Application of the Heck Reaction in the Synthesis of Heterocyclic Compounds. Heterocycles 2010, 81, 1979-2026. [CrossRef] 
8. Mazuela, J.; Tolstoy, P.; Pamies, O.; Andersson, P.G.; Dieguez, M. Phosphite-oxazole/imidazole ligands in asymmetric intermolecular Heck reaction. Org. Biomol. Chem. 2011, 9, 941-946. [CrossRef] [PubMed]

9. Enquist, P.-A.; Lindh, J.; Larhed, M. Open-air oxidative Heck reactions at room temperature. Green Chem. 2006, 8, 338-343. [CrossRef]

10. Du, X.L.; Suguro, M.; Hirabayashi, K.; Mori, A.; Nishikata, T.; Hagiwara, N.; Kawata, K.; Okeda, T.; Wang, H.F.; Fugami, K.; et al. Mizoroki-Heck Type Reaction of Organoboron Reagents with Alkenes and Alkynes. A Pd(II)-Catalyzed Pathway with $\mathrm{Cu}(\mathrm{OAc})_{2}$ as an Oxidant. Org. Lett. 2001, 3, 3313-3316. [CrossRef] [PubMed]

11. Liu, Y.; Li, D.; Park, C.-M. Stereoselective Synthesis of Highly Substituted Enamides by an Oxidative Heck Reaction. Angew. Chem. Int. Ed. 2011, 50, 7333-7336. [CrossRef] [PubMed]

12. Inamoto, K.; Kawasaki, J.; Hiroya, K.; Kondo, Y.; Doi, T. Tandem-type Pd(II)-catalyzed oxidative Heck reaction/intramolecular $\mathrm{C}-\mathrm{H}$ amidation sequence: A novel route to 4-aryl-2-quinolinones. Chem. Commun. 2012, 48, 4332-4334. [CrossRef] [PubMed]

13. Nitti, A.; Bianchi, G.; Po, R.; Swager, M.; Pasini, D. Domino Direct Arylation and Cross-Aldol for Rapid Construction of Extended Polycyclic $\pi$-Scaffolds. J. Am. Chem. Soc. 2017, 139, 8788-8791. [CrossRef] [PubMed]

14. Nitti, A.; Po, R.; Bianchi, G.; Pasini, D. Direct Arylation Strategies in the Synthesis of $\pi$-Extended Monomers for Organic Polymeric Solar Cells. Molecules 2017, 22, 21. [CrossRef] [PubMed]

15. Letizia, C.S.; Cocchiara, J.; Lalko, J.; Lapczynski, A.; Api, A.M. Review Fragrance material review on cinnamyl alcohol. Food Chem. Toxicol. 2005, 43, 837-866. [CrossRef] [PubMed]

16. Calo, V.; Nacci, A.; Monopoli, A.; Ferola, V. Palladium-Catalyzed Heck Arylations of Allyl Alcohols in Ionic Liquids: Remarkable Base Effect on the Selectivity. J. Org. Chem. 2007, 72, 2596-2601. [CrossRef] [PubMed]

17. Yusub, C.T.; Hossian, A.; Manna, M.K.; Jana, R. Chemo-, Regio- and Stereoselective Heck-Matsuda Arylation of Allylic Alcohols under Mild Conditions. Org. Biomol. Chem. 2015, 13, 4841-4845. [CrossRef]

18. Ambrogio, I.; Cacchi, S.; Fabrizi, G.; Goggiamani, A.; Sgalla, S. Regio- and Stereoselective Heck $\alpha$-Arylation of Cinnamyl Alcohols. Synlett 2009, 4, 620-624. [CrossRef]

19. Mino, T.; Kogure, T.; Abe, T.; Koizumi, T.; Fujita, T.; Sakamoto, M. Palladium-Catalyzed Allylic Arylation of Allylic Ethers with Arylboronic Acids Using Hydrazone Ligands. Eur. J. Org. Chem. 2013, 1501-1505. [CrossRef]

20. Maralhas, A.; Monteiro, A.; Martins, C.; Kranendonk, M.; Laires, A.; Rueff, J.; Rodrigues, A.S. Genotoxicity and endoreduplication inducing activity of the food flavouring eugenol. Mutagenesis 2006, 21, 199-204. [CrossRef] [PubMed]

21. Kaufman, T.S. The Multiple Faces of Eugenol. A Versatile Starting Material and Building Block for Organic and Bio-Organic Synthesis and a Convenient Precursor toward Bio-Based Fine Chemicals. J. Braz. Chem. Soc. 2015, 26, 1055-1085. [CrossRef]

22. Abdel Bar, F.M.; Khanfar, M.A.; Elnagar, A.Y.; Badria, F.A.; Zaghloul, A.M.; Ahmad, K.F.; Sylvester, P.W.; El Sayed, K.A. Design and pharmacophore modeling of biaryl methyl eugenol analogs as breast cancer invasion inhibitors. Bioorg. Med. Chem. 2010, 18, 496-507. [CrossRef] [PubMed]

23. Penn, L.; Shpruhman, A.; Gelman, D. Enantio- and Regioselective Heck-Type Reaction of Arylboronic Acids with 2,3-Dihydrofuran. J. Org. Chem. 2007, 72, 3875-3879. [CrossRef] [PubMed]

24. Dallmeir, K.; Carlini, E.A. Anesthetic, hypothermic, myorelaxant and anticonvulsant effects of synthetic eugenoderivates and natural analogues. Pharmacology 1981, 22, 113-127. [CrossRef] [PubMed]

25. Sawant, D.; Wagh, Y.; Kushal, B.; Panda, A.; Bhanage, B. Palladium polyether diphosphinite complex anchored in polyethylene glycol as an efficient homogeneous recyclable catalyst for the Heck reactions. Tetrahedron Lett. 2011, 52, 2390-2393. [CrossRef]

26. Bakkali, F.; Averbeck, S.; Averbeck, D.; Idaomar, M. Biological effects of essential oils-A review. Food Chem. Toxicol. 2008, 46, 446-475. [CrossRef] [PubMed]

27. Letizia, C.S.; Cocchiara, J.; Lalko, J.; Api, A.M. Review Fragrance material review on linalool. Food Chem. Toxicol. 2003, 41, 943-964. [CrossRef]

28. Raguso, R.A.; Pichersky, E. New perspectives in pollination biology: Floral fragrances A day in the life of a linalool molecule: Chemical communication in a plant-pollinator system. Part 1: Linalool biosynthesis in flowering plants. Plant Species Biol. 1999, 14, 95-120. [CrossRef] 
29. Berthiol, F.; Doucet, H.; Santelli, M. Synthesis of $\beta$-aryl ketones by tetraphosphine/palladium catalysed Heck reactions of 2- or 3-substituted allylic alcohols with aryl bromides. Tetrahedron 2006, 62, 4372-4383. [CrossRef]

30. Berthiol, F.; Doucet, H.; Santelli, M. Heck reactions of aryl halides with alk-1-en-3-ol derivatives catalysed by a tetraphosphine-palladium complex. Appl. Organometal. Chem. 2006, 20, 855-868. [CrossRef]

31. Calo, V.; Nacci, A.; Monopoli, A.; Cotugno, A. Palladium-nanoparticle-catalysed Ullmann reactions in ionic liquids with aldehydes as the reductants: Scope and mechanism. Chem. Eur. J. 2009, 15, 1272-1279. [CrossRef] [PubMed]

Sample Availability: Samples of the compounds are not available from the authors.

(C) 2018 by the authors. Licensee MDPI, Basel, Switzerland. This article is an open access article distributed under the terms and conditions of the Creative Commons Attribution (CC BY) license (http:// creativecommons.org/licenses/by/4.0/). 